\title{
Epidemiology of ANCA associated vasculitis
}

\author{
Wenche Koldingsnes ${ }^{1}$ and Hans C. Nossent ${ }^{2}$ \\ 1) Department of Rheumatology, University Hospital North Norway, Tromsø, Norway \\ 2) Department of Rheumatology, Institute of Clinical Medicine, University of Tromsø, Norway \\ Correspondence: Wenche Koldingsnes, Department of Rheumatology, University Hospital North Norway, N-9038 Tromsø, Norway \\ E-mail: wenche.koldingsnes@unn.no Telephone:+47 77627257 Telefax: + 4777627258
}

\begin{abstract}
ANCA associated vasculitis (AAV) comprises three syndromes with systemic vasculitis (Wegener's granulomatosis (WG), Churg Strauss syndrome (CSS) and microscopic polyangiitis (MPA)), which all involve small and medium sized vessels and are associated with antibodies against cytoplasmatic antibodies in neutrophils (ANCA). Polyarteritis nodosa (PAN) is included in this review as it also affects medium sized vessels, and has many clinical findings in common with the AAV.

Since the recognition of ANCA, increasing data have become available on the epidemiology of these vasculitidis. WG constitutes half of the AAV and its prevalence has increased from 30/million in the late 1980 's in the USA to 160/million in this century in northern Europe. The prevalence for the whole group of primary systemic vasculitides is now 300 /million in Sweden. The annual incidence of WG increased from 6.0/million to 14/million during the 1990's in Tromsø, but it is unknown if this is a true increase or the result of an increased awareness of the diagnosis. For the whole group of AAV, the annual incidence in most more recent studies is relatively constant over time and by geographical location, ranging from 13 to $21 /$ million. Nonetheless there are interesting differences in the prevalence of specific vasculitis between different geographical areas, as well as for sub specificities of ANCA.

There seems to be a South-North gradient for WG and PR3-ANCA with high figures reported from northern Europe and southern New Zealand. In European studies WG is 90\% PR3-ANCA positive. MPA which is predominantly MPO-ANCA associated are more frequent in the Mediterranean countries and also has an increasing gradient towards east-Asia, as almost all AAV in China and Japan are diagnosed as MPA, predominantly MPO-ANCA positive.

There are also some ethnic and gender differences. WG is most prevalent among Caucasians in the USA and in people with European ancestors in Paris and in New Zealand, less frequent in Africans and Asians. Several studies have shown that the highest incidence of WG is in males 60-70 years old. Females are younger at onset, and in children WG is most frequent in girls.

With better treatment (cyclophosphamide and corticosteroids), the survival of AAV has increased considerably. However disease control is not optimal, as most of the vasculitis present a remitting-relapsing course and organ damage is considerable. Hence, we are still looking to improve treatment regimens.
\end{abstract}

Key words: Wegener's granulomatosis; Microscopic polyangiitis; Churg Strauss syndrome; Polyarteritis nodosa; epidemiology; incidence; prevalence; vasculitis

\section{INTRODUCTION}

The term vasculitis designates a group of now more than fifteen different diseases, in which inflammation of the wall of blood vessels occurs in veins, arteries and/or capillaries. Depending on the size and localisation of the affected vessels, patients present with more or less clinically distinct symptoms. While most types of vasculitis were previously considered to be rare, this is no longer the case (1). In addition, vasculitides may cause severe morbidity and increase mortality due to vascular obstruction with tissue ischemia and infarction of several organ systems $(2,3)$.

Within the group of vasculitides, there is a distinct subgroup consisting of Microscopic Polyangiitis (MPA), Churg Strauss syndrome (CSS) and Wegener's granulomatosis (WG). These syndromes are all characterised by the presence of necrotizing lesions of small vessels and the regular presence of antibodies against cytoplasmatic antigens in neutrophils (ANCA) and therefore nowadays grouped together as ANCA associated vasculitis (AAV) (4-6). Polyarteritis nodosa (PAN) is not included in this group by most authors given its infrequent association with ANCA and its known (causal) relationship with viral hepatitis (7). However, as PAN affects similar vessels as AAV, PAN is often grouped along with the AAV. Increased scientific interest has resulted in enhanced management and has resulted in better outcomes in AAV over the last two decades $(2,8)$. Thus the epidemiology of $\mathrm{AAV}$ is of common interest.

\section{ClassificAtion CRITERIA}

The AAV follow a relapsing-remitting time course and account for considerable morbidity and mortality. 
They affect numerous organs, and are a major cause of kidney disease, caused by a necrotizing focal segmental glomerulonephritis, often leading to end stage renal failure, despite the best current treatment strategies. The lack of a unifying etiology on the one hand and the need for an accurate assessment to guide patient management on the other hand, is a constant challenge for clinicians involved in patient care. While it is essential to exclude infectious and other autoimmune diseases that can mimic primary vasculitis, the subsequent classification of the AAV is most often guided by classification criteria proposed by the American
College of Rheumatology (ACR) (9-12) (Table 1). These criteria were meant to help identify patients with specific vasculitic diagnoses within a large cohort of vasculitis patients and were based on expert diagnosis (9). Their main aim was to allow observational and interventional studies in groups of patients with similar disease in different regions. The resulting criteria had $82-88 \%$ sensitivity and $92-99 \%$ specificity for PAN (3 of 10 criteria), WG (2 of 4 criteria) and CSS (4 of 6 criteria) against the group of other vasculitis patients indicating at least $10 \%$ false negative and $5-10 \%$ false positive rates associated with the use of these schemes.

Table 1. American College of Rheumatology classification criteria for Wegener's granulomatosis (WG), Churg Strauss syndrome (CSS) and Polyarteritis nodosa (PAN) (10-12).

\begin{tabular}{|c|c|c|c|}
\hline \multicolumn{2}{|c|}{ Diagnosis } & \multirow{2}{*}{$\begin{array}{l}\text { Criterion } \\
\text { Nasal or oral inflammation }\end{array}$} & \multirow{2}{*}{$\begin{array}{l}\text { Definition } \\
\text { Development of painful or painless oral ulcers or purulent or bloody nasal } \\
\text { discharge }\end{array}$} \\
\hline WG & 1 & & \\
\hline & 2 & Abnormal chest radiograph & Chest radiograph showing the presence of nodules, fixed infiltrates, or cavities \\
\hline & 3 & Urinary sediment & $\begin{array}{l}\text { Microheamaturia ( }>5 \text { red blood cells per high power field) or red cell casts in } \\
\text { urine }\end{array}$ \\
\hline & 4 & $\begin{array}{l}\text { Granulomatous inflammation } \\
\text { on biopsy }\end{array}$ & $\begin{array}{l}\text { Histologic changes showing granulomatous inflammation within the wall of } \\
\text { an artery or in the perivascular or extravascular area (artery or arteriole) }\end{array}$ \\
\hline \multirow[t]{6}{*}{ CSS } & 1 & Asthma & History of wheezing or diffuse highpitched rales on expiration. \\
\hline & 2 & Eosinophilia & Eosinophilia $>10 \%$ on white blood cell differential count. \\
\hline & 3 & $\begin{array}{l}\text { Mononeuropathy or } \\
\text { polyneuropathy }\end{array}$ & $\begin{array}{l}\text { Development of mononeuropathy, multiple mononeuropathies, or } \\
\text { polyneuropathy (i.e., glove/stocking distribution) attributable to a systemic } \\
\text { vasculitis. }\end{array}$ \\
\hline & 4 & $\begin{array}{l}\text { Pulmonary infiltrates, } \\
\text { non-fixed }\end{array}$ & $\begin{array}{l}\text { Migratory or transitory pulmonary infiltrates on radiographs (not including } \\
\text { fixed infiltrates), attributable to a systemic vasculitis. }\end{array}$ \\
\hline & 5 & Paranasal sinus abnormality & $\begin{array}{l}\text { History of acute or chronic paranasal sinus pain or tenderness or radiographic } \\
\text { opacification of the paranasal sinuses. }\end{array}$ \\
\hline & 6 & Extravascular eosinophils & $\begin{array}{l}\text { Biopsy including artery, arteriole, or venule, showing accumulations of } \\
\text { eosinophils in extravascular areas. }\end{array}$ \\
\hline \multirow[t]{10}{*}{ PAN } & 1 & Weigth loss $\geq 4 \mathrm{~kg}$ & $\begin{array}{l}\text { Loss of } 4 \mathrm{~kg} \text { or more of body weight since illness began, not due to dieting or } \\
\text { other factors. }\end{array}$ \\
\hline & 2 & Livedo reticularis & Mottled reticular pattern over the skin of portions of the extremities or torso. \\
\hline & 3 & Testicular pain or tenderness & $\begin{array}{l}\text { Pain or tenderness of the testicles, not due to infection, trauma, or other } \\
\text { causes. }\end{array}$ \\
\hline & 4 & $\begin{array}{l}\text { Myalgias, weakness, or leg } \\
\text { tenderness }\end{array}$ & $\begin{array}{l}\text { Diffuse myalgias (excluding shoulder end hip girdle) or weakness of muscles } \\
\text { or tenderness of leg muscles }\end{array}$ \\
\hline & 5 & $\begin{array}{l}\text { Mononeuropathy or } \\
\text { polyneuropathy }\end{array}$ & Development of mononeuropathy, multiple neuropathies, or polyneuropathy. \\
\hline & 6 & Diastolic $\mathrm{BP}>90 \mathrm{~mm} \mathrm{Hg}$ & $\begin{array}{l}\text { Development of hypertension with diastolic blood pressure higher than } 90 \\
\mathrm{mmHg} \text {. }\end{array}$ \\
\hline & 7 & Elevated BUN or creatinine & $\begin{array}{l}\text { Elevation of blood urea nitrogen }(\mathrm{BUN})>40 \mathrm{mg} / \mathrm{dl} \text { or creatinine }>1.5 \mathrm{mg} / \mathrm{dl} \\
(132 \mu \mathrm{mol} / \mathrm{L}) \text {, not due to dehydration or obstruction. }\end{array}$ \\
\hline & 8 & Hepatitis B virus & Presence of he patitis B surface antigen or antibody in serum. \\
\hline & 9 & Arteriographic abnormality & $\begin{array}{l}\text { Arteriogram showing aneurysms or occlusions of the visceral arteries, not due } \\
\text { to arteriosclerosis, fibromuscular dysplasia, or other noninflammatory causes. }\end{array}$ \\
\hline & 10 & $\begin{array}{l}\text { Biopsy of small or medium- } \\
\text { sized artery containing poly- } \\
\text { morphnuclear neutrophils }\end{array}$ & $\begin{array}{l}\text { Histologic changes showing the presence of granulocytes or granulocytes and } \\
\text { mononuclear leucocytes in the artery wall. }\end{array}$ \\
\hline
\end{tabular}


Subsequent refinements to our thinking about vasculitis were made by an expert consensus meeting, the Chappel Hill Consensus Conference in 1994 that aimed to better define the various types of systemic vasculitis in order to increase our understanding of how various elements may contribute to the specific disease manifestations (13) (Table 2). This fundamentally different approach resulted in the description of MPA as a separate entity from PAN and also established the role for either histological proof or reliable surrogate markers of AAV in clinical practice.

The detection of ANCA has altered the clinical approach to patients with a possible vasculitic syndrome, but is neither incorporated in the ACR criteria nor in the CHCC definitions. This has led a group of doctors interested in epidemiology of vasculitis to develop a stepwise algorithm using both the ACR criteria, the CHCC definitions and ANCA result, as a method to permit epidemiological comparisons without confounding by classification (14). This algorithm, called EMEA algorithm, also defines the surrogate markers for the histological changes used in CHCC definitions (Table 3).

\section{DiagnOSTIC CONSIDERATIONS}

The gold standard for a diagnosis of AAV is histologic evidence of small vessel vasculitis in the context of a clinical constellation with respiratory and renal symptoms together with a positive ANCA result (15). Biopsy findings include leukocyte invasion of the vessel wall, ensuing vessel wall damage and extravasations of red blood cells, fibrinoid necrosis, thrombosis, and sometimes a granulomatous reaction. Importantly, negative biopsy findings do no necessarily exclude AAV given the potential for skip lesions in vessels (16).

The clinical constellation is often that of a patient with a (sub)acute presentation of a systemic inflammatory reaction with constitutional symptoms as fever, fatigue, tiredness and weight-loss together with more specific organ findings such as pulmonary-renal syndrome with nasal discharge, cough, dyspnoea and a uraemic/nephritic syndrome. Clinical findings in the different AAV are depicted in Table 4. Laboratory findings often reflect the degree of systemic inflammation with increased levels of acute phase reactants, the presence of anaemia of chronic disease and more

Table 2. Chappel Hill Consensus Conference's definitions of Wegener's granulomatosis (WG), Microscopic polyangiitis (MPA), Churg Strauss syndrome (CSS) and Polyarteritis nodosa (PAN) (13).

\begin{tabular}{ll}
\hline Diagnosis & Definitions \\
\hline WG & $\begin{array}{l}\text { Granulomatous inflammation involving the respiratory tract, and necrotizing vasculitis affecting small to medium- } \\
\text { sized vessels (e.g. capillaries, venules, arterioles and arteries). Necrotizing glomerulonephritis is common. } \\
\text { MPA }\end{array}$ \\
& $\begin{array}{l}\text { Necrotizing vasculitis, with few or no immune deposits, affecting small vessels (i.e. capillaries, venules or } \\
\text { arterioles). Necrotizing arteritis affecting small and medium-sized arteries may be present. Necrotizing } \\
\text { glomerulonephritis is very common. Pulmonary capillaritis often occurs. }\end{array}$ \\
& $\begin{array}{l}\text { Eosinophil-rich and and granulomatous inflammation involving the respiratory tract, and necrotizing vasculitis } \\
\text { affecting small to medium-sized vessels, and associated to asthma and eosinophilia. }\end{array}$ \\
& $\begin{array}{l}\text { Necrotizing inflammation of medium-sized or small arteries without glomerulonephritis or vasculitis in arterioles, } \\
\text { capillaries or venules. }\end{array}$ \\
\hline
\end{tabular}

Table 3. Surrogate markers for vasculitis in the EMEA algorithm (14).

\begin{tabular}{ll}
\hline Surrogate markers for granulomatous disease (Wegener's granulomatosis)* \\
\hline Upper airways & $\begin{array}{l}\text { Bloody nasal discharge and crusting for }>1 \text { month, or nasal ulceration } \\
\text { Chronic sinusitis, otitis media or mastoiditis for }>3 \text { months } \\
\text { Saddle nose deformity/destructive sinonasal disease } \\
\text { Retro-orbital mass or inflammation (pseudotumour) } \\
\text { Subglottic stenosis }\end{array}$ \\
Lower airways & $\begin{array}{l}\text { Radiologic evidence of fixed pulmonary infiltrates, nodules or cavitations present for }>1 \text { month } \\
\text { Bronchial stenosis }\end{array}$ \\
Surrogate markers for renal vasculitis (glomerulonephritis)* \\
\hline
\end{tabular}

* Only one surrogate marker is necessary to support the diagnosis. In all cases other causes must be excluded. 
specific signs of target organ dysfunction such as low levels of oxygenation, increased levels of serumcreatinin and the combined presence of hematuria and proteinuria. Ocular, skin and peripheral nerve affection are also often present $(17,18)$. The detection of a positive result for ANCA by either immunofluorescence or ELISA technique in a patient with systemic disease has a considerable clinical impact as it is often used as a surrogate marker in cases of suspected vasculitis (19). Nonetheless, ANCA testing by itself has only limited sensitivity and specificity for the diagnosis of AAV in a clinical setting (20).

\section{EPIDEMIOLOGY}

\section{Incidence and prevalence}

Classic PAN is the oldest of these systemic vasculitides, and was described by Kussmaul and Meyer in 1866 (21). WG was described in the 1930s, MPA in the 1940 s and CSS in the 1950s. However, early literature on the epidemiology of vasculitis has to be interpreted carefully as the term "polyarteritis nodosa" was used to describe any kind of small to medium sized vasculitis until the 1980s. Even though classification by the ACR criteria in 1990 was a great improvement for epidemiological studies, MPA was still included in the PAN diagnosis. As MPA was defined as a separate entity from PAN by the CHCC definition in 1994, it is important to check which disease criteria or definition is used when comparing different epidemiological studies. With this in mind, it is possible to look at the epidemiology of vasculitis in different time periods and different geographic areas. The early data on WG from Olmstead County, United States, in the period 1976-80 gives an annual incidence of 4.0/ million. In a study from Leicester, United Kingdom (UK), during the 1980s an increase in annual incidence/million from 0.7 to 2.8 is reported. The increased awareness of systemic vasculitis after ANCA was described in 1985 (22) may be the explanation for the observed increase in incidence of WG, also seen in our study from north
Norway (23). However, a true increase in incidence has not yet been ruled out. Incidences of WG in the adult population in various areas and time periods are shown in Table 5.

More convincing data exist on a true increase in prevalence for the AAV which can be explained both by earlier recognition of the diseases and with earlier and better treatment resulting in increased survival $(23,24)$. Prevalence data on AAV are listed in Table 6.

\section{Geographical variations}

WG has the highest annual incidence rate, of about 10 per million in northern Europe, while the incidence is only half of that in southern Europe (Table 5). This has led to a theory of a latitude effect on AAV characteristics, which was recently confirmed in the Southern hemisphere in a study that found WG to be much more prevalent in southern than in northern New Zealand (25). MPA, in contrast, has a higher incidence in southern Europe, and is also found more common in Asia. A recent study from Japan on AAV with renal involvement found a high annual incidence of MPA of 14.8/million, whereas there were no patients with WG (26). Most (91\%) patients were MPO-ANCA positive, while none were PR3-ANCA positive. Similar findings was seen in Bejing, China, where most patients with ANCA related disease had MPO-ANCA (213 anti-MPO versus 32 anti-PR3) (27). This is in contrast to Swedish findings of $35 \%$ MPO-ANCA positive and $59 \%$ PR3-ANCA positive in renal involved $\mathrm{WG}$ and MPA patients $(87 \%$ of $W G$ patients tested positive for PR3-ANCA) (28).

A referral hospital in Mexico City has observed a tripled incidence of WG over the last seven years (29). The Mexican WG patients have similar ANCA pattern as seen in northern Europe and in New Zealand with $80-90 \%$ of WG patients being PR3-ANCA positive and $10-15 \%$ MPO-ANCA positive. For MPA the reverse is found, $50-90 \%$ are MPO-ANCA positive while $5-40 \%$ are PR3-ANCA positive (28-30). Also in

Table 4. Clinical findings in ANCA associated vasculitis.

\begin{tabular}{lcccc}
\hline Organs involved & WG & MPA & CSS & PAN \\
\hline ENT & +++ & + & ++ polypi & - \\
Kidney & ++ & +++ & + & + HT \\
Nervous system & ++ & + & +++ & +++ \\
Lungs & ++ noduli & $+(+)$ diffuse & + transient & - \\
Eyes & ++ & + & $(+)$ & - \\
GI-tractus & $+(+)$ & $+(+)$ & ++ & +++ \\
Heart & + & $(+)$ & ++ & - \\
Skin & ++ & ++ & ++ & ++ \\
Muscle/joint & ++ & ++ & ++ & ++ \\
\hline ANCA & PR3 & MPO & MPO & negative \\
\hline
\end{tabular}

ENT: ear-nose and throat, GI: gastrointestinal, WG: Wegener's granulomatosis MPA: microscopic polyangiitis, CSS: Churg Strauss syndrome, PAN: polyarteritis nodosa, HT: arterial hypertension,

ANCA: anti neutrphil cytoplasmic antibody, PR3: proteinasis 3, MPO: myeloperoxidasis. 
India there seems to be a preponderance of WG (54\%) compared to MPA (18\%), however the frequency of PR3- and MPO-ANCA are more equal (48\% and 43\% respectively) (31). These findings all indicate latitude and east-west related difference both in the frequency of various vasculitides, but also in the ANCA pattern for different geographic areas.

\section{ANCA and ethnicity}

The reason for the different specificities of ANCA is unclear, but genetic variations may be important. It has been shown that WG, associated with PR3-ANCA, is more prevalent among Caucasian than black Americans (32). In New Zealand WG is twice as common among people of European ancestry compared to New Zealand Maori or Asian, which again has twice the prevalence of people identifying themselves as Pacific Islanders (25). In a multiethnic urban area in France, the prevalence of primary systemic vasculitis (AAV and PAN) was twice as high in individuals of European descent (107.4/million) as in non-European (52.5/million) (33).

Table 5. Incidence of ANCA associated vasculitis and PAN in the adult population.

\begin{tabular}{|c|c|c|c|c|c|c|c|c|}
\hline \multirow[b]{2}{*}{ Country } & \multirow{2}{*}{$\begin{array}{l}\text { Study } \\
\text { period }\end{array}$} & \multirow{2}{*}{$\begin{array}{c}\text { Study } \\
\text { population }\end{array}$} & \multicolumn{4}{|c|}{ Incidence/mill/year } & \multirow[b]{2}{*}{ Criteria } & \multirow[b]{2}{*}{ Ref } \\
\hline & & & WG & MPA & CSS & PAN & & \\
\hline United Kingdom, & $1988-92$ & 413000 & 8.7 & 6.8 & 1.5 & 6.8 & $\mathrm{WG}, \mathrm{CSS}, \mathrm{PAN}=\mathrm{ACR}$, & $(41)$ \\
\hline \multirow[t]{2}{*}{ Norwich } & $1993-97$ & & 10.3 & 8.9 & 3.7 & 8.9 & $\mathrm{MPA}=\mathrm{CHCC}$ & \\
\hline & Total & & 9.7 & 8.0 & 2.7 & 8.0 & & \\
\hline \multirow[t]{4}{*}{ Tromsø, Norway } & $1984-88$ & 371100 & 6.0 & & & & ACR & $(23)$ \\
\hline & $1989-93$ & & 7.5 & & & & & \\
\hline & $1994-98$ & & 14.4 & & & & & \\
\hline & Total & & 9.3 & & & & & \\
\hline Lugo. Spain & $1988-98$ & 208271 & 4.9 & 11.6 & 0.9 & 0.9 & $\mathrm{WG}, \mathrm{CSS}=\mathrm{ACR}$ & $(87)$ \\
\hline Norwich, UK & $1988-98$ & 413000 & 10.6 & 8.4 & 3.1 & 0 & $\mathrm{MPA}, \mathrm{PAN}=\mathrm{CHCC}$ & \\
\hline Tromsø, Norway & $1988-98$ & 371100 & 10.5 & 2.7 & 0.5 & 0.5 & & \\
\hline Northern Germany & $1998-2002$ & 2777275 & $\begin{array}{c}8.6 \\
(6.0-12.0)\end{array}$ & $\begin{array}{c}2.7 \\
(2.0-3.0)\end{array}$ & $\begin{array}{c}1.1 \\
(0-2.0)\end{array}$ & $\begin{array}{c}0.8 \\
(0.4-2.0)\end{array}$ & $\mathrm{CHCC}$ & $(40)$ \\
\hline Miyazaki, Japan & $2000-04$ & 968950 & 0 & $\begin{array}{c}14.8 \\
\text { Includes } \\
\text { RLV }\end{array}$ & 0 & & $\begin{array}{l}\text { WG, CSS }=\text { ACR, MPA }=\text { CHCC } \\
\text { RLV = necrotizing vascular injury } \\
\text { confined to the kidney. } \\
\text { All patients had renal involvement } \\
\text { and positive ANCA test. }\end{array}$ & (26) \\
\hline
\end{tabular}

Table 6. Prevalence of ANCA associated vasculitis.

\begin{tabular}{|c|c|c|c|c|c|c|c|c|c|}
\hline \multirow[b]{2}{*}{ Country } & \multirow{2}{*}{$\begin{array}{l}\text { Time of } \\
\text { prevalence* }\end{array}$} & \multirow{2}{*}{$\begin{array}{c}\text { Study } \\
\text { population }\end{array}$} & \multicolumn{5}{|c|}{ Prevalence/mill } & \multirow[b]{2}{*}{ Criteria } & \multirow[b]{2}{*}{ Ref } \\
\hline & & & WG & MPA & CSS & PAN & PSV & & \\
\hline USA, & $1986-90$ & 248 million & 26 & & & & & ICD-9 discharge diagnosis & (32) \\
\hline New York & (5-year) & 18 million & 32 & & & & & & \\
\hline Germany, & 1994 & & & & & & & $\mathrm{CHCC}$ & $(88)$ \\
\hline North & (1-year) & 449500 & 58 & 9 & 7 & 9 & & & \\
\hline South & & 426500 & 42 & 0 & 2 & 2 & & & \\
\hline Norway, south & $\begin{array}{l}1996 \\
\text { (1-year) }\end{array}$ & 150500 & 53 & & 13 & 33 & & ACR & (89) \\
\hline $\begin{array}{l}\text { United Kingdom, } \\
\text { Norwich }\end{array}$ & 1997 (pp) & 413000 & 63 & & & & 145 & $\begin{array}{l}\text { WG, } \mathrm{CSS}, \mathrm{PAN}=\mathrm{ACR}, \\
\mathrm{MPA}=\mathrm{CHCC}\end{array}$ & $(41)$ \\
\hline Norway, north & 1998 (pp) & 460000 & 95 & & & & & ACR & (23) \\
\hline France, Paris & $\begin{array}{l}2000 \\
\text { (1-year) }\end{array}$ & 1093500 & 24 & 25 & 11 & 31 & 90 & $\begin{array}{l}\mathrm{WG}, \mathrm{CSS}, \mathrm{PAN}=\mathrm{ACR}, \\
\mathrm{MPA}=\mathrm{CHCC}\end{array}$ & (33) \\
\hline Sweden, south & $2002(\mathrm{pp})$ & 287500 & $\begin{array}{l}129 \\
160 * *\end{array}$ & 94 & 14 & $31 * *$ & $299 * *$ & $\begin{array}{l}\mathrm{WG}, \mathrm{CSS}=\mathrm{ACR}, \\
\mathrm{PAN} \sim \mathrm{ACR}, \mathrm{MPA}=\mathrm{CHCC}\end{array}$ & $(38)$ \\
\hline New Zealand, & $2003(\mathrm{pp})$ & 481000 & 94 & 37 & & 0 & & $\mathrm{WG}, \mathrm{CSS}=\mathrm{ACR}$ & $(30)$ \\
\hline Canterbury & 5-year & & 131 & 58 & 4 & 0 & & $\mathrm{MPA}=\mathrm{CHCC}$ & \\
\hline
\end{tabular}

* Time given for point prevalence (pp) or period prevalence (n-year prevalence).

** The EMEA algoritm is used to for classification, including ANCA and surrogate markers for granulomatous involvement in respiratory tract and for glomerulonephritis (14).

PSV (primary systemic vasculitides) $=\mathrm{AAV}+\mathrm{PAN}$ 


\section{Genetic contributions}

Despite uncertainty about its aetiopathogenesis, AAV are considered to be autoimmune diseases where a genetic inclination to autoimmune reactions can be triggered by environmental factors. Although case reports have illustrated that familial clustering does occur, there have so far been no systemic reporting on familial aggregation in AAV (34). Genome-wide microarray scanning studies have not been reported, although single centre studies have reported on candidate genes in AAV. Alpha-1 anti-trypsin (AAT) is a physiological inhibitor of proteinase-3 (PR3) which is one of the antigens targeted by c-ANCA. Carriage of a defective allele in the coding region for AAT at the protease inhibitor locus (Pi) was the first reported genetic risk factor for the development of anti-PR-3 positive AAV (35) and may lead to increased PR-3 expression and increased risk for relapse in WG patients, while PR-3 gene polymorphism does not seem to contribute to PR-3 expression (36). Other association studies have found no or only weak associations between AAV and polymorphic cytokine, HLA, and Fcgamma receptor genes (37).

\section{Age and gender}

Mean age at onset of WG is 50 years in most studies and was stable over 15 years in our study from northern Norway $(23,33,38,39)$. However, in Germany, age at onset has increased with 15 years from 40-49 years (1966-1993) to 60 years (1998-2002) (40). MPA patients is older at diagnosis compared to WG patients. In European studies MPA is diagnosed at 60 years $(33,38)$, while in New Zealand and in Japan the MPA patients are 70 years at diagnosis (26). There are less epidemiological data on CSS and PAN, but mean age at onset for CSS is about 50 years, while onset of PAN is at age $45-48$ years $(33,38)$.

In both WG and MPA the age and gender-specific incidence rate show increase with age, most obvious in males. There is an overall peak in the 65-74 year age group in Europe, in the 70-74 year age group of MPA and RLV in Japan, and 70-79 year group of WG in New Zealand $(25,26,30,41)$. In the study from northern Norway we found a clear age-specific incidence top only in males (65-74 years). The less prominent peak incidence in females occurred at younger age (45-54 years), and moreover, in the whole cohort of WG patients with onset of disease from 10-84 years of age, all patients with childhood onset were girls (23). Also other studies in children report more WG in girls than in boys (42).

In the adult population the male to female ratio of 1.3-1.6 in WG $(23,33,38)$. In studies from Paris and Sweden there is an opposite male-female ratio of 0.5 0.9 in MPA, while the data on PAN and CSS are more conflicting, with a male-female ratio of $1.5-0.3$ and $1.7-1.0$, respectively $(33,38)$.

\section{Annual and seasonal variations}

The etiology of the AAV and PAN is unknown except for the association of PAN with Hepatitis B virus infection (43). The onset of WG, very often involving the upper airways has led to the hypothesis that inhaled agents or infections could be triggering factors. Some studies have showed a seasonal variation, supporting an infectious etiology $(44,45)$. However there are now conflicting results concerning seasonal variation in onset of AAV $(23,32,46,47)$. Also an annual variation in onset has been shown in WG (23), as in giant cell arteritis (48), but this phenomenon has to be confirmed in more studies.

\section{Environmental factors}

The geographical variations in AAV and the possible seasonal and annual variations in onset may reflect environmental influence. A number of factors have been reported to be associated with the development of vasculitis, including various infections, silica, hydrocarbons, inhaled fumes and particulates, drug, allergy, vaccination and farming.

\section{Infections}

Infection has been postulated as the cause of AAV vasculitis, for $\mathrm{WG}$, since the first description of the disease, yet no proof exists. However, classic PAN is closely related to Hepatitis B virus (HBV) and cryoglobulinaemia to Hepatitis $C$ virus $(49,50)$. A number of other viruses have been related to vasculitis. Cytomegalovirus has been reported to mimic WG, and parvovirus has been associated with $\mathrm{WG}$ and PAN (31). Also bacteria have been proposed as triggering factors for vasculitis, especially is staphylococcus aureus associated to disease relapse in WG (51).

\section{Silica}

AAV have been associated with exposure to particulate silica, like quartz, granite, sandstone or grain dust. The high levels of air pollution and silica dust after the earthquake in Kobe, Japan, in 1995, and the subsequent increase in MPO-ANCA-associated vasculitis, suggested a causal relationship (52). Six case-control studies have found significant associations between AAV and silica exposure, but with some conflicting results for the specific diagnoses of WG and MPA (5357). The most recent study from the USA found significant association only with higher lifetime exposure to silica, and indicated that crop harvesting might imply special risk (58).

\section{Farming}

Farming in the year prior to onset of AAV was associated with an increased risk of developing WG and MPA (OR 2.7 and 6.3 respectively), but not CSS in a study from the UK (55). The study could not distinguish between crops and livestock, but the association appeared to be stronger for livestock. An earlier study 
from the USA failed to find association between WG and farming (46).

\section{Inhaled fumes and hydrocarbons}

A case-control study from the USA reported association of inhaled fumes and particulate materials, with WG compared to healthy and rheumatic disease controls, but not to respiratory disease controls. For pesticides there was significant difference also to respiratory disease controls (46). Conflicting results exist for exposure to metals and welding fumes $(54,55)$, as for exposure to occupational hydrocarbons and solvents $(55,59)$.

\section{Drugs, allergy, vaccinations}

A large number of drugs have been associated with vasculitis, most often hypersensitivity vasculitis, but propylthiouracil and hydralazine have also been reported in association with AAV. In a review of 250 MPO-positive systemic vasculitis patients, 30 patients with the highest MPO-ANCA titer were examined for exposure to hydralazine, propylthiouracil, allopurinol, penicillamine or sulphasalazine. Among these high titered AAV patients $60 \%$ had used one or two of these drugs within 9 months prior to onset of disease (60). However, a possible association was not confirmed in another study of 586 patients treated with propylthiouracil, as only one case of vasculitis was found (61).

Leukotriene receptor antagonists have been linked to onset of CSS in several patients. However, recent studies raises some doubt about the relation, as it seems that patients experience a flare in their asthma requiring intensifying treatment, including leukotriene receptor antagonists prior to onset of the vasculitis $(62,63)$.
Two case-control studies have shown significantly more allergy during the last year prior to onset of primary systemic vasculitis than in healthy controls. This also holds true for the specific diagnosis of WG, but with conflicting results for MPA and CSS $(55,64)$. Autoimmune reactions, including AAV have been reported to follow vaccinations $(65)$, but more data is needed to state a clear relation.

\section{MORTALITY/PROGNOSIS}

\section{Mortality}

The prognosis for AAV has changed dramatically during the last 50 years, most notable for WG. In the 1950 s the mean survival of untreated WG was 5 months with less than $10 \%$ surviving 2 years (66). After the introduction of cyclophosphamide and corticosteroids as standard treatment, patients now experience a one year survival of $93 \%$ and a 5-year and 10 -year survival of $79 \%$ and $75 \%$ respectively (24). Still the mortality risk ratio is 4 compared to the general population (67), and $5-10 \%$ of WG patients die in active disease during the first 3 months after diagnosis (24).

The increased mortality risk is associated with higher age; a rise of each decade in age increasing the risk of death in WG patients with a hazard ratio of 2.18 (24). This is illustrated with the increased mortality in patients aged $>50$ years from northern Norway (Figure 1) and is confirmed in other studies $(68,69)$. Also renal involvement at diagnosis (68), especially severe renal impairment in a degree demanding dialysis, is predictor of reduced survival (24). Patients who had developed permanent organ damage at diagnosis, were also at increased risk of death in our study from northern Norway.

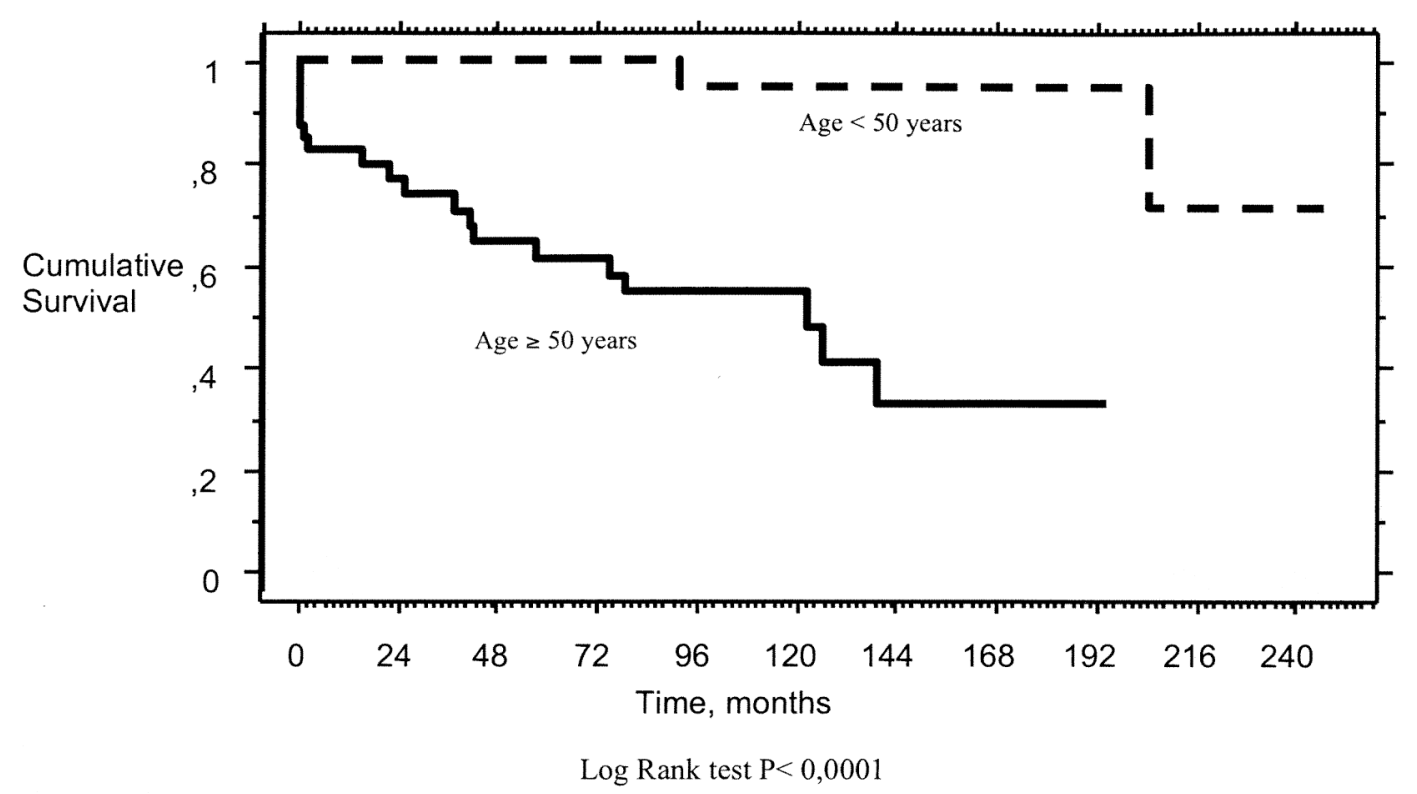

Figure 1. Kaplan Meier survival plots for 79 WG patients with a mean follow up of 76 months, from northern Norway (unpublished). 
The 5-year survival rate in MPA is between $45 \%$ and $75 \%$ which is worse than in WG $(2,70,71)$. Patient survival in CSS is $60-97 \%$ at 5 years $(72,73)$ depending on the presence at diagnosis of one or more of the five factors related to worse outcome: proteinuria $>1$ $\mathrm{g} /$ day, creatinine $>1.58 \mathrm{mg} / \mathrm{dl}$, gastrointestinal involvement, cardiomyopathy or neurological involvement (74). This five factor score has been shown to predict reduced survival also in MPA and PAN, though PAN (without HBV) has the best survival of these diagnoses, with a 10 -year survival rate close to $80 \%(75)$.

\section{Relapse}

Up to $90 \%$ of patients with AAV go into remission during the first 3-6 months of treatment. Most AAV however, shows a chronic relapsing course, which demands close follow-up and long-term therapy with immunosuppressive therapy.

The relapse rate is highest in $\mathrm{WG}$, with a cumulative relapse rate of more than $60 \%$ depending on time of follow-up and the intensity of maintenance treatment $(18,73)$. The relapse rate is increased in PR3ANCA positive patients (76), and a rise in cANCA or PR3-ANCA titer predicts relapse (77). The relapse rate in MPA is lower than in WG (78). In a French study following patients for more than 7 years, the relapse rate in MPA was 35\% and in CSS $20 \%$. PAN revealed the lowest relapse rate, with $20 \%$ in non-HBV associated PAN and $8 \%$ in the HBV associated PAN (75).

In WG patients from northern Norway we found that less intensive treatment during the first 6 months was related to increased risk of relapse. A cumulative cyclophosphamide dose of $<10 \mathrm{~g}$, and high dose prednisolone ( $\geq 20 \mathrm{mg} /$ day) for less than 2.75 months, increased the hazard ratio for relapse with 2.8 and 2.4 respectively (18).

Chronic nasal carriage of staphylococcus aureus is found in many patients with $\mathrm{WG}$, and is related to increased risk of relapse (79). Adjuvant remission maintenance treatment with trimethoprim-sulfamethooxazole reduced the relapse rate in one study (76).

\section{Organ damage}

Organ damage occurs early in AAV, best studied in WG $(24,80)$. Damage can be studied using the vasculitis damage index (VDI) (80). Using the VDI, we showed that the increase in damage was 6 times higher during the first 6 months after diagnosis compared to the next 18 months. This early damage was mainly due to disease activity $(93 \%)$, while treatment related damage increased later in the disease course (18). The early damage was related to disease activity at onset of therapy, and could in our study be reduced by longer time on cyclophosphamide during the first 6 months. Treatment protocols using pulse cyclophosphamide resulted in less late damage compared to treatment with daily oral cyclophosphamide (24).

Nasal and sinus dysfunction is the most frequent damage in WG (61\% in our study), hearing loss is seen in about a third of WG patients, visual loss in 8-9\% and saddle nose in $16 \%(24,81)$. Peripheral neuropathy is frequent $(43 \%)$, but complaint on pulmonary symptoms was only reported by $24 \%$ of patients after 5 years, although $80 \%$ of patients had previous lung involvement (82). End stage renal disease (ESRD) occurs in about $20 \%$ of patients with AAV $(24,83)$. Reduced renal survival was related to severe renal involvement in terms of dialysis dependence at start of treatment in our study (24). The relationship between ESRD and initial serum creatinine and dialysis dependency was also seen in another Norwegian study (67).

\section{Malignancy}

The increased life expectancy in AAV is due to more rapid recognition and aggressive treatment of the disease. In most patients this will include the use of cytotoxic drugs, in particular the use of oral or intravenous cyclophosphamide, that exerts its action by forming crosslinks between and within DNA strands and ultimately lead to cell death. While most active metabolites are oxidized, a portion is converted into acrolein that is a known bladder toxicant. Not surprisingly, increased longevity for WG is thus associated with an increased risk of late onset cancer, which mainly can be attributed to the use of cyclophosphamide $(84,85)$. Cancer risk is not increased in patients that never receive cyclophosphamide, while high cumulative doses of cyclophosphamide put AAV patients at risk for hematological, bladder and skin malignancies after 7-18 years of disease (84). The known carcinogenic effects of acrolein on bladder epithelium are mainly a problem in patients treated with oral cyclophosphamide $(8,24,86)$.

\section{CONCLUSION}

With a population prevalence of vasculitides of $300 /$ million, they represent big challenges not only to the treating physician, but also to the total health care system. Remission rates and survival in AAV have increased during the last 50 years, but disease relapses, organ damage and late malignancy still represents big challenges, and the optimal treatment is yet to be found.

\section{REFERENCES}

1. Mahr AD, Neogi T, Merkel PA. Epidemiology of Wegener's granulomatosis: Lessons from descriptive studies and analyses of genetic and environmental risk determinants. Clin Exp Rheumatol 2006; 24 (2 Suppl 41): S82-S91. 
2. Lane SE, Watts RA, Shepstone L, Scott DG. Primary systemic vasculitis: clinical features and mortality. QJM 2005; 98 (2): 97-111.

3. Iglesias-Gamarra A, Restrepo JF, Matteson EL. Small-vessel vasculitis. Curr Rheumatol Rep 2007 ; 9 (4): 304-311.

4. Selamet U, Kovaliv YB, Savage CO, Harper L. ANCA-associated vasculitis: new options beyond steroids and cytotoxic drugs. Expert Opin Investig Drugs 2007; 16 (5): 689-703.

5. Weidner S, Geuss S, Hafezi-Rachti S, Wonka A, Rupprecht HD. ANCA-associated vasculitis with renal involvement: an outcome analysis. Nephrol Dial Transplant 2004; 19 (6): 1403-1411.

6. Falk RJ, Jennette JC. Thoughts about the classification of small vessel vasculitis. J Nephrol $2004 ; 17$ (Suppl 8): S3-S9.

7. Guillevin L, Lhote F. Classification and management of necrotising vasculitides. Drugs 1997; 53 (5): 805 816.

8. Koldingsnes W, Gran JT, Omdal R, Husby G. Wegener's granulomatosis: long-term follow-up of patients treated with pulse cyclophosphamide. Br J Rheumatol 1998; 37 (6): 659-664.

9. Bloch DA, Michel BA, Hunder GG, McShane DJ, Arend WP, Calabrese LH et al. The American College of Rheumatology 1990 criteria for the classification of vasculitis. Patients and methods. Arthritis Rheum 1990; 33 (8): 1068-1073.

10. Leavitt RY, Fauci AS, Bloch DA, Michel BA, Hunder GG, Arend WP et al. The American College of Rheumatology 1990 criteria for the classification of Wegener's granulomatosis. Arthritis Rheum 1990; 33 (8): 1101-1107.

11. Masi AT, Hunder GG, Lie JT, Michel BA, Bloch DA, Arend WP et al. The American College of Rheumatology 1990 criteria for the classification of Churg-Strauss syndrome (allergic granulomatosis and angiitis). Arthritis Rheum 1990; 33 (8): 1094-1100.

12. Lightfoot RW, Jr, Michel BA, Bloch DA, Hunder GG, Zvaifler NJ, McShane DJ et al. The American College of Rheumatology 1990 criteria for the classification of polyarteritis nodosa. Arthritis Rheum 1990; 33 (8): 1088-1093.

13. Jennette JC, Falk RJ, Andrassy K, Bacon PA, Churg J, Gross WL et al. Nomenclature of systemic vasculitides. Proposal of an international consensus conference. Arthritis Rheum 1994; 37 (2): 187-192.

14. Watts R, Lane S, Hanslik T, Hauser T, Hellmich B, Koldingsnes W et al. Development and validation of a consensus methodology for the classification of the ANCA-associated vasculitides and polyarteritis nodosa for epidemiological studies. Ann Rheum Dis 2007; 66 (2): 222-227.

15. Harper L, Weidanz F. Small vessel vasculitides. Medicine 2006; 34 (11): 456-463.

16. Lie JT. Histopathologic specificity of systemic vasculitis. Rheum Dis Clin North Am 1995; 21 (4): 883-909.

17. Haubitz M. ANCA-associated vasculitis: diagnosis, clinical characteristics and treatment. Vasa 2007; 36 (2): 81-89.

18. Koldingsnes W, Nossent JC. Baseline features and initial treatment as predictors of remission and relapse in Wegener's granulomatosis. J Rheumatol 2003; 30 (1): 80-88.

19. Lapraik C, Watts R, Bacon P, Carruthers D, Chakravarty K, D'Cruz D et al. BSR and BHPR guidelines for the management of adults with ANCA associated vasculitis. Rheumatology 2007; 46 (10): 1615-1616.

20. Mandl LA, Solomon DH, Smith EL, Lew RA, Katz JN, Shmerling RH. Using antineutrophil cytoplasmic antibody testing to diagnose vasculitis: can test-ordering guidelines improve diagnostic accuracy? Arch Intern Med 2002; 162 (13): 1509-1514.

21. Kussmaul A, Maier R. Ueber eine bisher nicht beschriebene eigenthümliche Arterienerkrankung (Periarteritis nodosa), die mit Mobus Brightii und rapid fortschreitender allgemeiner Muskellähmung einhergeht. Deutsches Archiv für Klinische Medicin 1866; 1 (1): 484.

22. van der Woude FJ, Rasmussen N, Lobatto S, Wiik A, Permin H, van Es LA et al. Autoantibodies against neutrophils and monocytes: tool for diagnosis and marker of disease activity in Wegener's granulomatosis. Lancet 1985; 1 (8426): 425-429.

23. Koldingsnes W, Nossent H. Epidemiology of Wegener's granulomatosis in northern Norway. Arthritis Rheum 2000; 43 (11): 2481-2487.

24. Koldingsnes W, Nossent H. Predictors of survival and organ damage in Wegener's granulomatosis. Rheumatology 2002; 41 (5): 572-581.

25. O'Donnell JL, Stevanovic VR, Frampton C, Stamp LK, Chapman PT. Wegener's granulomatosis in New Zealand: evidence for a latitude-dependent incidence gradient. Intern Med J 2007; 37 (4): 242-246.

26. Fujimoto S, Uezono S, Hisanaga S, Fukudome K, Kobayashi S, Suzuki K et al. Incidence of ANCAassociated primary renal vasculitis in the Miyazaki Prefecture: the first population-based, retrospective, epidemiologic survey in Japan. Clin J Am Soc Nephrol 2006; 1 (5): 1016-1022.

27. Xin G, Zhao MH, Wang HY. Detection rate and antigenic specificities of antineutrophil cytoplasmic antibodies in Chinese patients with clinically suspected vasculitis. Clin Diagn Lab Immunol 2004; 11 (3): $559-562$. 
28. Westman KW, Bygren PG, Olsson H, Ranstam J, Wieslander J. Relapse rate, renal survival, and cancer morbidity in patients with Wegener's granulomatosis or microscopic polyangiitis with renal involvement. $J A m$ Soc Nephrol 1998; 9 (5): 842-852.

29. Flores-Suarez LF, Villa AR. Spectrum of Wegener granulomatosis in a Mexican population. Ann N Y Acad Sci 2007; 1107: 400-409.

30. Gibson A, Stamp LK, Chapman PT, O'Donnell JL. The epidemiology of Wegener's granulomatosis and microscopic polyangiitis in a Southern Hemisphere region. Rheumatology 2006; 45 (5): 624-628.

31. Watts RA, Lane S, Scott DG. What is known about the epidemiology of the vasculitides? Best Pract Res Clin Rheumatol 2005; 19 (2): 191-207.

32. Cotch MF, Hoffman GS, Yerg DE, Kaufman GI, Targonski P, Kaslow RA. The epidemiology of Wegener's granulomatosis. Estimates of the five-year period prevalence, annual mortality, and geographic disease distribution from population-based data sources. Arthritis Rheum 1996; 39 (1): 87-92.

33. Mahr A, Guillevin L, Poissonnet M, Ayme S. Prevalences of polyarteritis nodosa, microscopic polyangiitis, Wegener's granulomatosis, and Churg-Strauss syndrome in a French urban multiethnic population in 2000: a capture-recapture estimate. Arthritis Rheum 2004; 51 (1): 92-99.

34. Seo P, Luqmani RA, Flossmann O, Hellmich B, Herlyn K, Hoffman GS et al. The future of damage assessment in vasculitis. J Rheumatol 2007; 34 (6): 1357-1371.

35. Esnault VL, V. Alpha 1-antitrypsin genetic polymorphism in ANCA-positive systemic vasculitis. Kidney Int 1993; 43 (6): 1329-1332.

36. Abdgawad M. Increased neutrophil membrane expression and plasma level of proteinase 3 in systemic vasculitis are not a consequence of the $-564 \mathrm{~A} / \mathrm{G}$ promotor polymorphism. Clin Exp Immunol 2006; 145 (1): 63-70.

37. Kallenberg CG. Genetics of ANCA-associated vasculitides. Cleveland Clin J Med 2002; 69 Suppl 2: SII61-3.

38. Mohammad AJ, Jacobsson LT, Mahr AD, Sturfelt G, Segelmark M. Prevalence of Wegener's granulomatosis, microscopic polyangiitis, polyarteritis nodosa and Churg Strauss syndrome within a defined population in southern Sweden. Rheumatology 2007; 46 (8): 1329-1337.

39. Gordon M, Luqmani RA, Adu D, Greaves I, Richards N, Michael J et al. Relapses in patients with a systemic vasculitis. QJM 1993; 86 (12): 779-789.

40. Reinhold-Keller E, Herlyn K, Wagner-Bastmeyer R, Gross WL. Stable incidence of primary systemic vasculitides over five years: results from the German vasculitis register. Arthritis Rheum 2005; 53 (1): 93-99.

41. Watts RA, Lane SE, Bentham G, Scott DG. Epidemiology of systemic vasculitis: a ten-year study in the United Kingdom. Arthritis Rheum 2000; 43 (2): 414-419.

42. Belostotsky VM, Shah V, Dillon MJ. Clinical features in 17 paediatric patients with Wegener granulomatosis. Pediatr Nephrol 2002; 17 (9): 754-761.

43. Guillevin L, Lhote F, Jarrousse B, Bironne P, Barrier J, Deny P et al. Polyarteritis nodosa related to hepatitis B virus. A retrospective study of 66 patients. Ann Med Interne (Paris) 1992; 143 Suppl 1: 63-74.

44. Carruthers DM, Watts RA, Symmons DP, Scott DG. Wegener's granulomatosis - increased incidence or increased recognition? Br J Rheumatol 1996; 35 (2): 142-145.

45. Raynauld JP, Bloch DA, Fries JF. Seasonal variation in the onset of Wegener's granulomatosis, polyarteritis nodosa and giant cell arteritis. J Rheumatol 1993; 20 (9): 1524-1526.

46. Duna GF, Cotch MF, Galperin C, Hoffman DB, Hoffman GS. Wegener's granulomatosis: role of environmental exposures. Clin Exp Rheumatol 1998; 16 (6): 669-674.

47. Mahr A, Artigues N, Coste J, Aouba A, Pagnoux C, Guillevin L. Seasonal variations in onset of Wegener's granulomatosis: increased in summer? J Rheumatol 2006; 33 (8): 1615-1622.

48. Salvarani C, Gabriel SE, O'Fallon WM, Hunder GG. The incidence of giant cell arteritis in Olmsted County, Minnesota: apparent fluctuations in a cyclic pattern. Ann Intern Med 1995; 123 (3): 192-194.

49. Guillevin L. Virus-associated vasculitides. Rheumatology 1999; 38 (7): 588-590.

50. Pagnoux C, Cohen P, Guillevin L. Vasculitides secondary to infections. Clin Exp Rheumatol $2006 ; 24$ (2 Suppl 41): S71-S81.

51. Popa ER, Tervaert JW. The relation between Staphylococcus aureus and Wegener's granulomatosis: current knowledge and future directions. Intern Med 2003; 42 (9): 771-780.

52. Yashiro M, Muso E, Itoh-Ihara T, Oyama A, Hashimoto K, Kawamura $\mathrm{T}$ et al. Significantly high regional morbidity of MPO-ANCA-related angitis and/or nephritis with respiratory tract involvement after the 1995 great earthquake in Kobe (Japan). Am J Kidney Dis 2000; 35 (5): 889-895.

53. Hogan SL, Satterly KK, Dooley MA, Nachman PH, Jennette JC, Falk RJ. Silica exposure in anti-neutrophil cytoplasmic autoantibody-associated glomerulonephritis and lupus nephritis. J Am Soc Nephrol 2001; 12 (1): 134-142.

54. Nuyts GD, Van Vlem E, De Vos A, Daelemans RA, Rorive G, Elseviers MM et al. Wegener granulomatosis is associated to exposure to silicon compounds: a case-control study. Nephrol Dial Transplant 1995; 10 (7): 1162-1165. 
55. Lane SE, Watts RA, Bentham G, Innes NJ, Scott DG. Are environmental factors important in primary systemic vasculitis? A case-control study. Arthritis Rheum 2003; 48 (3): 814-823.

56. Gregorini G, Ferioli A, Donato F, Tira P, Morassi L, Tardanico R et al. Association between silica exposure and necrotizing crescentic glomerulonephritis with p-ANCA and anti-MPO antibodies: a hospital-based casecontrol study. Adv Exp Med Biol 1993; 336: 435-440.

57. Stratta P, Canavese C, Messuerotti A, Fenoglio I, Fubini B. Silica and renal diseases: no longer a problem in the 21 st century? J Nephrol 2001; 14 (4): 228-247.

58. Hogan SL, Cooper GS, Savitz DA, Nylander-French LA, Parks CG, Chin H et al. Association of silica exposure with anti-neutrophil cytoplasmic autoantibody small-vessel vasculitis: a population-based, case-control study. Clin J Am Soc Nephrol 2007; 2 (2): 290-299.

59. Pai P, Bone JM, Bell GM. Hydrocarbon exposure and glomerulonephritis due to systemic vasculitis. Nephrol Dial Transplant 1998; 13 (5): 1321-1323.

60. Choi HK, Merkel PA, Walker AM, Niles JL. Drug-associated antineutrophil cytoplasmic antibody-positive vasculitis: prevalence among patients with high titers of antimyeloperoxidase antibodies. Arthritis Rheum 2000; 43 (2): 405-413.

61. Frenkel J, Tellez R, Reyes C, Gonzalez G, Michaud P. [Major adverse reactions to propylthiouracil in 586 cases of hyperthyroidism]. Rev Med Chil 1993; 121 (11): 1289-1294.

62. Guilpain P, Pagnoux C, Lhote F, Mouthon L, Guillevin L. [Antileukotrienes and Churg-Strauss syndrome]. Presse Med 2007; 36 (5 Pt 2): 890-894.

63. Hauser T, Mahr AD, Metzler C, Coste J, Sommerstein R, Gross WL et al. Montelukast and the risk of ChurgStrauss symdrome: A case-crossover study. Clin Exp Rheumatol 2007; 25 (Suppl 44): S-96.

64. Cuadrado MJ, D'Cruz D, Lloyd M, Mujic F, Khamashta MA, Hughes GR. Allergic disorders in systemic vasculitis: a case-controlled study. Br J Rheumatol 1994; 33 (8): 749-753.

65. Wraith DC, Goldman M, Lambert PH. Vaccination and autoimmune disease: what is the evidence? Lancet 2003; 362 (9396): 1659-1666.

66. Walton EW, Leggat PO. Wegener's granulomatosis. J Clin Pathol 1956; 9 (1): 31-37.

67. Aasarod K, Iversen BM, Hammerstrom J, Bostad L, Vatten L, Jorstad S. Wegener's granulomatosis: clinical course in 108 patients with renal involvement. Nephrol Dial Transplant 2000; 15 (5): 611-618.

68. Reinhold-Keller E, Beuge N, Latza U, de Groot K, Rudert H, Nolle B et al. An interdisciplinary approach to the care of patients with Wegener's granulomatosis: long-term outcome in 155 patients. Arthritis Rheum 2000; 43 (5): 1021-1032.

69. Bligny D, Mahr A, Toumelin PL, Mouthon L, Guillevin L. Predicting mortality in systemic Wegener's granulomatosis: a survival analysis based on 93 patients. Arthritis Rheum 2004; 51 (1): 83-91.

70. Guillevin L, Durand-Gasselin B, Cevallos R, Gayraud M, Lhote F, Callard P et al. Microscopic polyangiitis: clinical and laboratory findings in eighty-five patients. Arthritis Rheum 1999; 42 (3): 421-430.

71. Westman KW, Selga D, Isberg PE, Bladstrom A, Olsson H. High proteinase 3-anti-neutrophil cytoplasmic antibody (ANCA) level measured by the capture enzyme-linked immunosorbent assay method is associated with decreased patient survival in ANCA-associated vasculitis with renal involvement. J Am Soc Nephrol 2003; 14 (11): 2926-2933.

72. Guillevin L, Cohen P, Gayraud M, Lhote F, Jarrousse B, Casassus P. Churg-Strauss syndrome. Clinical study and long-term follow-up of 96 patients. Medicine 1999; 78 (1): 26-37.

73. Mukhtyar C, Flossmann O, Hellmich B, Bacon PA, Cid MC, Cohen Tervaert JW et al. Outcomes from studies of Antineutrophil Cytoplasm Antibody Associated Vasculitis: a systematic review by the EULAR Systemic Vasculitis Task Force. Ann Rheum Dis 2007, doi:10.1136/ard.2007.071936.

74. Guillevin L, Lhote F, Gayraud M, Cohen P, Jarrousse B, Lortholary O et al. Prognostic factors in polyarteritis nodosa and Churg-Strauss syndrome. A prospective study in 342 patients. Medicine 1996; 75 (1): 17-28.

75. Gayraud M, Guillevin L, Le Toumelin P, Cohen P, Lhote F, Casassus P et al. Long-term followup of polyarteritis nodosa, microscopic polyangiitis, and Churg-Strauss syndrome: analysis of four prospective trials including 278 patients. Arthritis Rheum 2001; 44 (3): 666-675.

76. Stegeman CA, Tervaert JW, De Jong PE, Kallenberg CG. Trimethoprim-sulfamethoxazole (co-trimoxazole) for the prevention of relapses of Wegener's granulomatosis. Dutch Co-Trimoxazole Wegener Study Group. $N$ Engl J Med 1996; 335 (1): 16-20.

77. Boomsma MM, Stegeman CA, van der Leij MJ, Oost W, Hermans J, Kallenberg CG et al. Prediction of relapses in Wegener's granulomatosis by measurement of antineutrophil cytoplasmic antibody levels: a prospective study. Arthritis Rheum 2000; 43 (9): 2025-2033.

78. Jayne D, Rasmussen N, Andrassy K, Bacon P, Tervaert JW, Dadoniene J et al. A randomized trial of maintenance therapy for vasculitis associated with antineutrophil cytoplasmic autoantibodies. $N$ Engl J Med 2003; 349 (1): 36-44. 
79. Stegeman CA, Tervaert JW, Sluiter WJ, Manson WL, De Jong PE, Kallenberg CG. Association of chronic nasal carriage of Staphylococcus aureus and higher relapse rates in Wegener granulomatosis. Ann Intern Med 1994; 120 (1): 12-17.

80. Exley AR, Bacon PA, Luqmani RA, Kitas GD, Gordon C, Savage CO et al. Development and initial validation of the Vasculitis Damage Index for the standardized clinical assessment of damage in the systemic vasculitides. Arthritis Rheum 1997; 40 (2): 371-380.

81. Hoffman GS, Kerr GS, Leavitt RY, Hallahan CW, Lebovics RS, Travis WD et al. Wegener granulomatosis: an analysis of 158 patients. Ann Intern Med 1992; 116 (6): 488-498.

82. Koldingsnes W, Jacobsen EA, Sildnes T, Hjalmarsen A, Nossent HC. Pulmonary function and high-resolution CT findings five years after disease onset in patients with Wegener's granulomatosis. Scand J Rheumatol 2005; 34 (3): 220-228.

83. Jayne D. Evidence-based treatment of systemic vasculitis. Rheumatology 2000; 39 (6): 585-595.

84. Faurschou M, Sorensen IJ, Mellemkjaer L, Loft AGR, Thomsen BS, Tvede N, Baslund B. Malignancies in Wegener's granulomatosis: incidence and relation to cyclophosphamide therapy in a cohort of 293 patients. $J$ Rheumatol 2008; 35 (1): 100-105.

85. Knight A, Askling J, Ekbom A. Cancer incidence in a population-based cohort of patients with Wegener's granulomatosis. Int J Cancer 2002; 100 (1): 82-85.

86. Talar-Williams C, Hijazi YM, Walther MM, Linehan WM, Hallahan CW, Lubensky I et al. Cyclophosphamideinduced cystitis and bladder cancer in patients with Wegener granulomatosis. Ann Intern Med 1996; 124 (5): 477-484.

87. Watts RA, Lane SE, Scott DG, Koldingsnes W, Nossent H, Gonzalez-Gay MA et al. Epidemiology of vasculitis in Europe. Ann Rheum Dis 2001; 60 (12): 1156-1157.

88. Reinhold-Keller E, Zeidler A, Gutfleisch J, Peter HH, Raspe HH, Gross WL. Giant cell arteritis is more prevalent in urban than in rural populations: results of an epidemiological study of primary systemic vasculitides in Germany. Rheumatology 2000; 39 (12): 1396-1402.

89. Haugeberg G, Bie R, Bendvold A, Larsen AS, Johnsen V. Primary vasculitis in a Norwegian community hospital: a retrospective study. Clin Rheumatol 1998; 17 (5): 364-368. 